\title{
Modeling Future Yield and Irrigation Demand of Rice Paddy in Korea
}

\author{
우리나라 미래의 논 벼 생산량과 관개요구량 모델링
}

\author{
Nkomozepi, Temba · Chung, Sang-Ok \\ 은코모제피 템바 ${ }^{*}$ 정상옥 ${ }^{* *+}$
}

\begin{abstract}
기후변화에 따른 기온상승과 강우패턴의 변화에 의한 농업의 취약성에 대한 연구는 주요 관심분야이다. 본 연구에서 기후변화가 한국 의 $2021 \sim 2040$ (2030s), 2051 2070 (2060s) 및 2081 2100 (2090s)의 벼의 생산량과 관개요구량에 미치는 영향을 모의발생하여 분석 하였다. 세 가지 대표농도경로 (Representative Concentration Pathways: RCPs)에 대한 12개의 전지구 기후모형이 추정한 기후자료로부터 미래의 작물 물 요구량, 유효강우량, 관개요구량을 물수지 방법으로 계산하였다. Water Accounting Rice Model (WARM) 벼 작물모형을 보정하여 벼 생산량 추정에 이용하였다. 벼 생산량은 금세기 말에는 최대 $40 \%$ 까지 감소하는 것으로 나타났다. 생산량은 특히 경남과 충 남지방에서 크게 증가하는 것으로 나타났다. 생산량과 관개요구량의 시공간적인 불확실성을 분석한 바, 경북과 전남에서 2090s, RCP8.5 때 불확실성이 가장 큰 것으로 나타났다. 미래에 일부 지역은 벼농사에 적합하지 않을 수도 있을 것으로 추정되었으며 기후변화 대응 방안에 대한 연구가 필요할 것으로 판단된다.
\end{abstract}

Keywords: Paddy rice; climate change; Irrigation; RCP, WARM

\section{INTRODUCTION}

A multi-disciplinary approach to promote agricultural productivity and the water use efficiency is required to cope with climate change. In addition to affecting crop water supply and consumption, climate change will also affect crop yields. Agricultural production is vulnerable to the shifts in the rainfall, radiation and temperature patterns caused by climate change (Supit et al., 2012). Quantifying and understanding the dynamics of the biomass produced per amount of water used at the crop level is essential for facing agro-economic and environmental challenges (Tallec et al., 2013). Integrated assessments of interdisciplinary content that couple scientific and policy issues have been used to investigate the potential climate change and its impacts in strategic planning (Van Minnen et al., 2000).

\footnotetext{
* 경북대학교 농업토목공학과 박사과정

** 경북대학교 농업토목공학과 교수

$\dagger \quad$ Corresponding author Tel.: +82-53-950-5734

Fax: +82-53-950-6752

E-mail: sochung@knu.ac.kr

2013년 10월 7일 투고

2013년 12월 12일 심사완료

2013년 12월 16일 게재확정
}

Estimates of the magnitude and vulnerability of irrigation water demand to climate change are further necessitated by the fact that demand for irrigation water is also increasing despite that most surface and groundwater water resources are presently fully exploited (Weatherhead and Knox, 2000). It is widely accepted that irrigation demands vary from one location to another and moisture shortage sensitivity varies with the crop growth stage. Jang et al., (2007) observed that generally, water balance models are used to compute the irrigation water demand from observed climate data (evapotranspiration (ET) and effective rainfall) and farm management practices. To date, numerous studies have used the irrigation-decision support tool developed by the United Nations Food and Agriculture Organization (FAO) CropWat model (Chung, 2013; Chung and Nkomozepi, 2012).

On the other hand, crop yield response to climate change can be assessed using simple regression approaches. However, the application of more complex process-based crop simulation models is justified by their additional capacity to analyze the dynamic interactions between environment, genotype and management factors (Angulo et al., 2013). Crop models are able to simulate measured grain yield and other factors with accuracy under diverse environments if 
input information is sufficient (Asseng et al., 2013).

Rice yields have significantly increased over the last century as a result of better management of pests and diseases, genetic improvement and higher applications of fertilizer (Semenov et al., 2012). In the Republic of Korea (Korea hereafter), the average ambient temperature and rainfall increased by $1.5{ }^{\circ} \mathrm{C}$ and $10 \%$, respectively, between 1904 and 2000 (Yoo et al., 2013). In the event of accelerated increase in temperature caused by climate change, the rates of grain filling and leaf senescence will increase while the durations of grain filling and leaf senescence will decrease, thereby decreasing yields (Kim et al., 2011). Simultaneously, the increase in the ambient temperature will exacerbate crop water demand and moisture losses associated with water storage and conveyance (Mehta et al., 2013). Chung (2013) estimated that the total volumetric irrigation water demand will increase by at least $5 \%$ by the end of this century. Review of literature has revealed that while a handful of studies have focused on the nationwide irrigation demand, a few studies have considered the potential impact of climate change on both the irrigation demand and yield on a nationwide scale. A combined study of irrigation demand and crop yields will allow the potential impacts of climate change on the demand to be taken in context with the accompanying impacts on yield. The objective of this study is to explore the impact of climate change on the yield and the net irrigation demand of paddy rice in Korea by using General Circulation Model (GCM) ensemble climate projections.

\section{MATERIAL AND METHODS}

\section{Study area}

Korea lies in the Far East and covers an area of about $45 \%$ of the Korean peninsula $\left(98,477 \mathrm{~km}^{2}\right)$, with altitude between $0 \mathrm{~m}$ and 1,950 $\mathrm{m}$ above sea level. Korea has eight administrative provinces which can be studied independently, namely Gyeonggi (A), Gangwon (B), Chungnam (C), Chungbuk (D), Gyeongbuk (E), Jeonbuk (F), Jeonam (G) and Gyeongnam (H) as shown in Fig. 1. The climate of Korea is the Asian monsoon with average temperatures that range from about - $10{ }^{\circ} \mathrm{C}$ in winter to about $30{ }^{\circ} \mathrm{C}$ in summer. Two-thirds of the annual rainfall falls in the summer months, June to

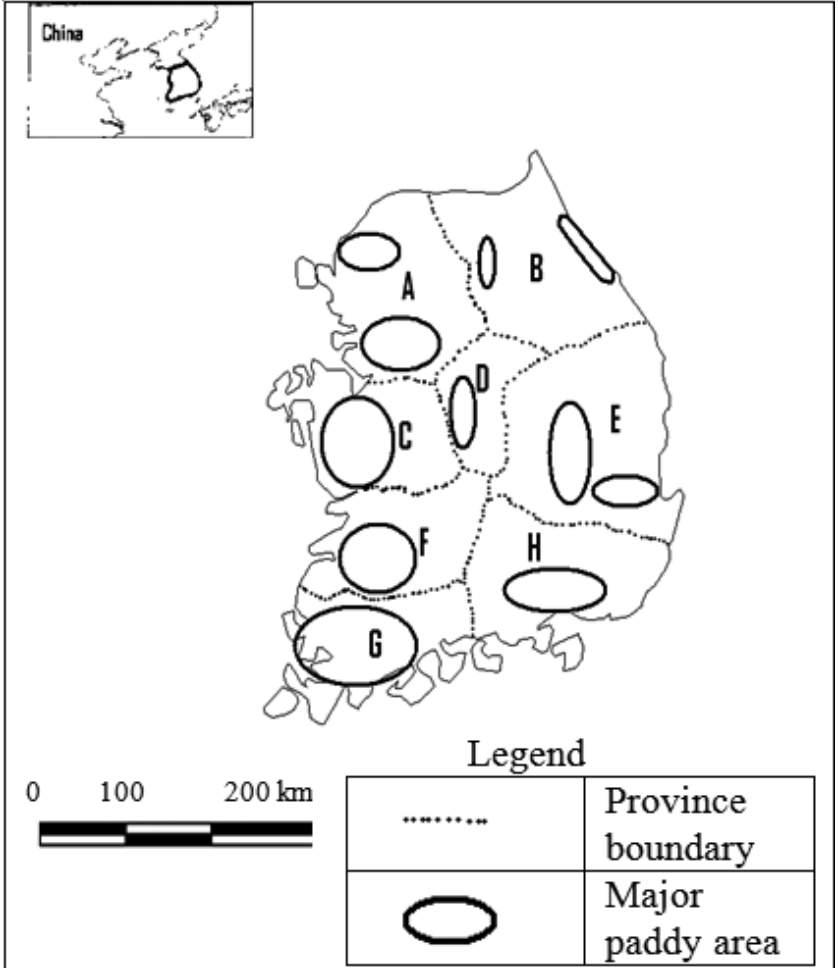

Fig. 1 Rice growing areas of Korea (Chung, 2013)

September. Rice is the main staple crop in Korea. Approximately $80 \%$ of the paddy fields in Korea are irrigated (Yoo et al., 2013). The rice growing period is from May to September and monoculture is the general practice. May is the nursery period and seedlings are transplanted in late May. About $77 \%$ of the paddy fields lie on inceptisol soils. Irrigation water is supplied from May to September to keep the water depth at $5-10 \mathrm{~cm}$ and rice is harvested in late October (Chung, 2013).

\section{Climate data}

Climate data (i.e. temperature, rainfall, radiation, wind speed and relative humidity) for eight administrative provinces for 1971-2000 (baseline) were downloaded from the Korean Meteorological Administration (www.kma.go.kr). Thereafter, climate data from 12 GCMs and 3 RCPs for 1971-2000 (1985s), 2021-2040 (2030s), 2051-2070 (2060s) and 20802100 (2090s) were extracted from an online database courtesy of the World Climate Research Program's Working Group on Coupled Modeling (CMPI5). The selected models are shown in Table 1. The mean of the absolute (for 
Table 1 Selected GCMs

\begin{tabular}{c|l}
\hline Model & \multicolumn{1}{c}{ Modeling Center } \\
\hline \hline ACCESS1.0 & CSIRO (Commonwealth Scientific and Industrial Research Organisation, Australia), and BOM (Bureau of Meteorology, Australia) \\
\hline BCC-CSM1 & Beijing Climate Center, China Meteorological Administration \\
\hline CCSM4 & National Center for Atmospheric Research \\
\hline CNRM-CM5 & Centre National de Recherches Meteorologiques / Centre Europeen de Recherche et Formation Avancees en Calcul Scientifique \\
\hline FGOALS-G2 & LASG, Institute of Atmospheric Physics, Chinese Academy of Sciences \\
\hline GFDL-CM3 & Geophysical Fluid Dynamics Laboratory \\
\hline GISS-E2 & NASA Goddard Institute for Space Studies \\
\hline HADGEM-ES & Met Office Hadley Centre, Instituto Nacional de Pesquisas Espaciais, Korea Meteorological Administration \\
\hline INMCM4 & Institute for Numerical Mathematics \\
\hline IPSL-CM5A & Institut Pierre-Simon Laplace \\
\hline MROC5 & $\begin{array}{l}\text { Atmosphere and Ocean Research Institute (The University of Tokyo), National Institute for Environmental Studies, and Japan Agency for } \\
\text { Marine-Earth Science and Technology }\end{array}$ \\
\hline MRI-CGCM3 & Meteorological Research Institute \\
\hline
\end{tabular}

temperature) and relative differences (rest of parameters) between the GCM baseline and future scenarios were used to perturb the observed baseline using the Long Ashton Research Station weather generator (LARS-WG). Scenarios refer to single realizations of the climate, generated for either the baseline or future climate using global climate models (GCMs) to be input into the yield or net irrigation requirement (NIR) model (Ledbetter et al., 2012). The LARS-WG is widely used for climate changes studies to generate daily site-specific scenarios of future and past climate, by considering changes in both mean climate and climate variability (Kim et al., 2013). Of the 3 RCPs used in this study, RCP2.6, RCP4.5 and RCP8.5 represent the low, medium and high scenarios of radiative forcing and greenhouse gas emissions examined by the climate modeling community.

\section{Crop model: WARM}

The Water Accounting Rice Model (WARM) is a simplified daily time step model for the simulation of growth and development of paddy rice crops (Confalonieri et al., 2010). WARM has an advantage over other crop models in that it has a user friendly interface and it is designed to account solely for the micrometeorological peculiarities of paddy fields. WARM can also account for diseases and cold shock induced spikelet sterility that influence the final yield (Confalonieri et al., 2009). Crop development is based on the thermal time accumulated between a base temperature and a cutoff temperature, optionally modulated by a photoperiodic factor. In crop growth, aboveground biomass rate is calculated on a daily time step as shown below (eq. 1.):

$$
A G B_{d}=R U E_{a c t} \times 0.5 \cdot \operatorname{Rad} \cdot\left(1-e^{-k L A I}\right)
$$

where $\operatorname{Rad}\left(\mathrm{MJ} \mathrm{m} \mathrm{m}^{-2} \mathrm{~d}^{-1}\right)$ is daily global solar radiation, $1-e^{-k L A I}$ is the fraction of photosynthetically active radiation $(P A R)$ intercepted by the canopy, $k$ is light extinction coefficient, LAI $\left(\mathrm{m}^{2} \mathrm{~m}^{-2}\right)$ is the leaf area index, RUE act $(\mathrm{g}$ $\mathrm{MJ}^{-1}$ ) is actual PAR use efficiency calculated as shown below (eq. 2):

$$
R U E_{\text {act }}=R U E_{\max } \cdot T_{\text {lim }} \cdot\left(R a d_{-} F\right) \cdot\left(D V S_{-} F\right)
$$

where RUEmax $\left(\mathrm{kg} \mathrm{MJ}^{-1}\right)$ is the radiation use efficiency value (crop parameter) not limited by water, nutrients, pest, diseases, senescence, excess of radiation, temperature, damages. Tlim, Rad_F and DVS_F are unit less factors in the range 0 (maximum stress) -1 (no limitation) accounting for temperature limitations, saturation of the enzymatic chains, and senescence phenomena, respectively. $T_{\lim }$ is temperaturelimitation factor, calculated by the equation below (eq. 3);

$$
T_{\lim }=\left[\left(\frac{T-T_{b}}{T_{o}-T_{b}}\right)\left(\frac{T_{c}-T}{T_{c}-T_{c}}\right)^{\frac{T_{c}-T_{b}}{T_{o}-T_{b}}}\right]^{C}
$$


Table 2 WARM parameters

\begin{tabular}{|c|c|c|c|c|c|}
\hline Development parameters & Value & unit & Growth parameters & Value & Unit \\
\hline Base $\mathrm{T}$ before emergence & 12 & ${ }^{\circ} \mathrm{C}$ & Radiation use efficiency & 2.4 & $\mathrm{~g} \mathrm{MJ}^{-1}$ \\
\hline Max. T before emergence & 40 & ${ }^{\circ} \mathrm{C}$ & Extinction coefficient for solar radiation & 0.5 & - \\
\hline GDDs to reach emergence & 80 & ${ }^{\circ} \mathrm{C}$ day & Base $\mathrm{T}$ for biomass accumulation & 12 & ${ }^{\circ} \mathrm{C}$ \\
\hline Base $\mathrm{T}$ after emergence & 12 & ${ }^{\circ} \mathrm{C}$ & Optimum T for biomass accumulation & 28 & ${ }^{\circ} \mathrm{C}$ \\
\hline \multirow{2}{*}{ Max T after emergence } & \multirow{2}{*}{40} & \multirow{2}{*}{${ }^{\circ} \mathrm{C}$} & Max T for biomass accumulation & 35 & ${ }^{\circ} \mathrm{C}$ \\
\hline & & & Leaf area index at emergence & 0.02 & $\mathrm{~m}^{2} \mathrm{~m}^{-2}$ \\
\hline \multirow{2}{*}{ GDDs emergence - flowering } & \multirow{2}{*}{970} & \multirow{2}{*}{${ }^{\circ} \mathrm{C}$ day } & Specific leaf area at emergence & 27 & $\mathrm{~m}^{2} \mathrm{~kg}^{-1}$ \\
\hline & & & Specific leaf area end tillering & 18 & $\mathrm{~m}^{2} \mathrm{~kg}^{-1}$ \\
\hline GDDs flowering - maturity & 550 & ${ }^{\circ} \mathrm{C}$ day & Fraction of biomass partitioned to leaves at emergence & 0.8 & - \\
\hline Development stage at harvest & 2.0 & - & Kc full canopy & 1.2 & - \\
\hline
\end{tabular}

where $T\left({ }^{\circ} \mathrm{C}\right)$ is the mean daily air temperature, $T_{c}\left({ }^{\circ} \mathrm{C}\right)$ is the ceiling air temperature at which crop growth ceases, $T_{0}\left({ }^{\circ} \mathrm{C}\right)$ is the optimal air temperature at which the maximum rate of development occurs, $T_{b}\left({ }^{\circ} \mathrm{C}\right)$ is the base air temperature for crop growth, $C$ is a shape factor set equal to 1.8 to allow the beta-function to approximately cross linear progression between $T_{b}$ and $T_{o}$ at $T_{\lim }=0.5$.

The factors accounting for saturation of the enzymatic chains involved with photosynthesis (Rad_F) and for the effect of senescence (DVS_F) are calculated using empirical functions. Daily aboveground biomass $\left(\mathrm{kg} \mathrm{m}^{-2} \mathrm{~d}^{-1}\right)$ is partitioned to leaves, panicles and stems. Partitioning to panicles starts at the panicle initiation stage (PI) and peaks at the beginning of the ripening phase. A daily factor accounting for spikelet sterility due to cold shocks during the period between panicle initiation and heading is also calculated. The parameters used in this study are shown in Table 2. The parameters in Table 2 were determined for the Korean Japonica rice from calibration, literature and model default parameters (Confalonieri et al., 2006). For the parameter values in Table 2 , the $\mathrm{R}^{2}$ ranged for rice yields from 0.63 to 0.92 when simulated and observed values were compared. The authors assumed that here is no significant variation in soil types, elevation and physical geomorphology across the 8 provinces.

\section{Crop model Sensitivity analysis}

To illustrate the possible changes in the rice yield and NIR, their sensitivity to a combination of changes in rainfall and temperature were computed and illustrated by response surface diagrams. Values of the baseline rainfall were multiplied by factors of 0.5 to 1.5 in increments of 0.25 while $-2{ }^{\circ} \mathrm{C}$ to $7{ }^{\circ} \mathrm{C}$ were added to the baseline temperature in increments of $0.5{ }^{\circ} \mathrm{C}$.

\section{Net irrigation water requirement (NIR)}

Crop water demand consists of (1) a land preparation demand of $140 \mathrm{~mm}$, (2) nursery or seedbed demand and (3) a water requirement to maintain an inundated soil environment in a paddy field after transplanting (Guerra et al., 1998). The water requirement after transplanting can be estimated by multiplying the reference evapotranspiration $\left(\mathrm{ET}_{0}\right)$ and the crop coefficient $\left(\mathrm{K}_{\mathrm{c}}\right)$. $\mathrm{ET}_{0}$ is based on the atmospheric water demand and the crop and soil surface characteristics and was estimated using a modified Microsoft Excel spreadsheet for computing the reference evapotranspiration $\left(\mathrm{ET}_{0}\right)$ by using the FAO Penman-Monteith equation (Lupia, 2013). Kc refers to the ratio of the actual ET to the ETo and it is determined by the climate, crop's conditions and the cultivation practices (Djaman and Irmak, 2013). The difference between the water demand and effective rainfall represents the net irrigation requirement (NIR). Effective rainfall upper limit was estimated using a method for paddy rice based on daily readings (Dastane, 1978). In this method, $80 \%$ of the daily rainfall is considered effective if it is more than half of the daily reference evapotranspiration $\left(\mathrm{ET}_{0}\right)$ and daily rainfall of less than half of the $\mathrm{ET}_{\mathrm{o}}$ is disregarded.

\section{Trend and uncertainty analysis}

The impact of climate change on the temperature, rainfall, 
NIR and yield were assessed quantitatively and presented in box and whisker plots. To facilitate for easier comparison across time periods and provinces, the results of the different scenarios will be presented as relative (future/baseline) or absolute changes (future - baseline; for temperature only). In addition the coefficient of for rainfall, sunshine hours, relative humidity and wind speed, max. and min. temperatures and rice yield were analyzed. In the box and whisker plots in this study, the box plot whiskers indicate the full data range, the box shows the interquartile-range and the line across the boxes represents the mean. For each scenario, the means were used to detect trend patterns while the ranges and interquartile ranges or standard deviation were used to assess for the GCM ensemble uncertainty. Uncertainty refers to any departure from the unachievable ideal of completely deterministic knowledge of a system (Asseng et al., 2013). Finally, the irrigation water use efficiency (IWUE) ( $\mathrm{kg} \mathrm{ha}^{-1} \mathrm{~mm}^{-1}$ ) was analyzed (Eq. 4). The IWUE represents an assessment of the total surface and groundwater withdrawn with respect to the crop yield in the future. In the context of this study, the IWUE is used to identify the provinces of unsustainable water use. The IWUE is not universally applicable, and was adopted in this study after careful consideration of the dynamics of the NIR and rainfall which generally fall between 0.9 and 1.2 of the baseline values in the future. It was assumed that if the IWUE was below 16 $\mathrm{kg} \mathrm{ha}^{-1} \mathrm{~mm}^{-1}$, a potential vulnerable province was identified. An IWUE of above $20 \mathrm{~kg} \mathrm{ha}^{-1} \mathrm{~mm}^{-1}$ indicates provinces where irrigation water use is acceptable.

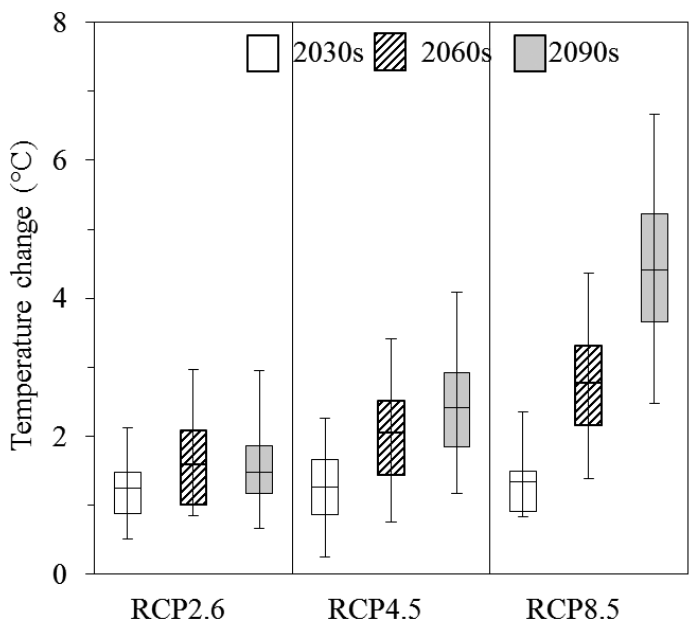

$$
I W U E=\frac{\text { Crop yield }}{\text { Irrigation Water applied }}
$$

\section{RESULTS AND DISCUSSION}

\section{Future climate}

Fig. 2 shows the projected changes in temperature and rainfall. The $12 \mathrm{GCMs}$ indicate significant warming of the country in the future particularly in the 2090s. The RCP2.6 peaks in the 2060s and the increasing trend slightly declines in the 2090s. The trends in the temperature follow the trends in the radiative forcing. The model disagreement (uncertainty) also increases in the future and is highest in the 2090s. Temperature uncertainty ranges from 0.6 to $1.6{ }^{\circ} \mathrm{C}$. Generally, rainfall was projected to increase in the future. There are strong increasing trends that persist until the 2060s and decline thereafter towards the 2090s. The uncertainty troughs in the 2060s and is highest in the 2090s. Rainfall uncertainty ranges from 0.06 to 0.13 .

\section{Variability of the parameter values during the baseline}

Fig. 3 shows the coefficient of variation (CV) of the annual means of weather parameters and rice yield over the baseline period (1971-2000). The CV is a normalized measure of dispersion or variability of parameters, and it is used to analyze the variability in the context of the mean of the data. There is high spatial variability of the CVs across the provinces. Rainfall has the highest $\mathrm{CV}$ which is mostly

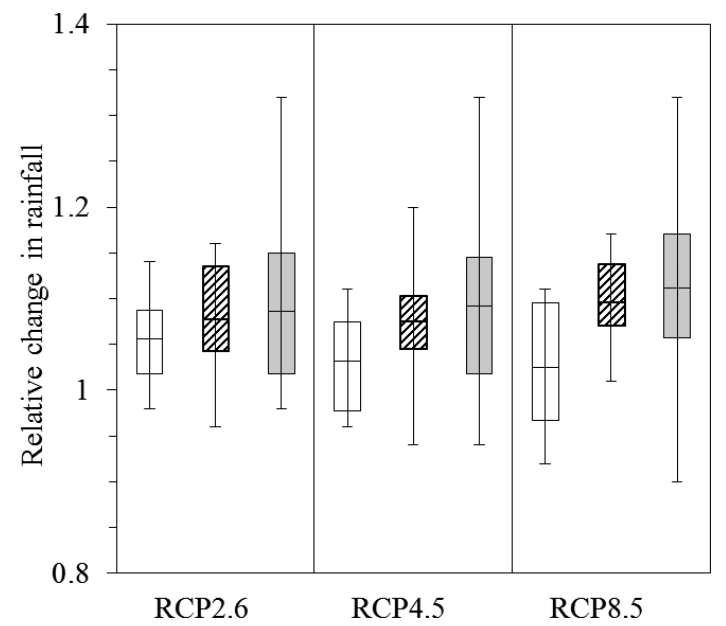

Fig. 2 Projected temperature change and relative changes in rainfall 


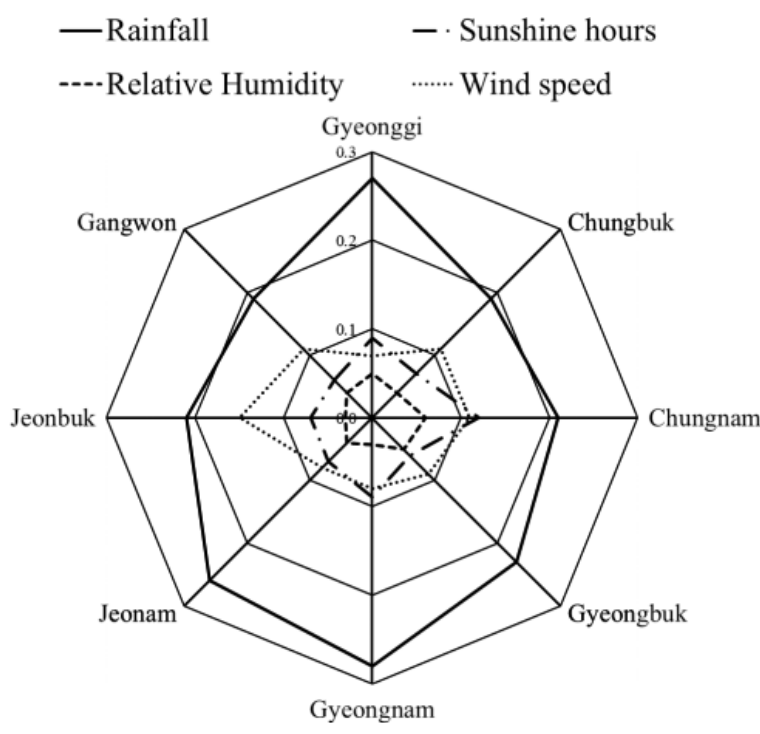

(a)

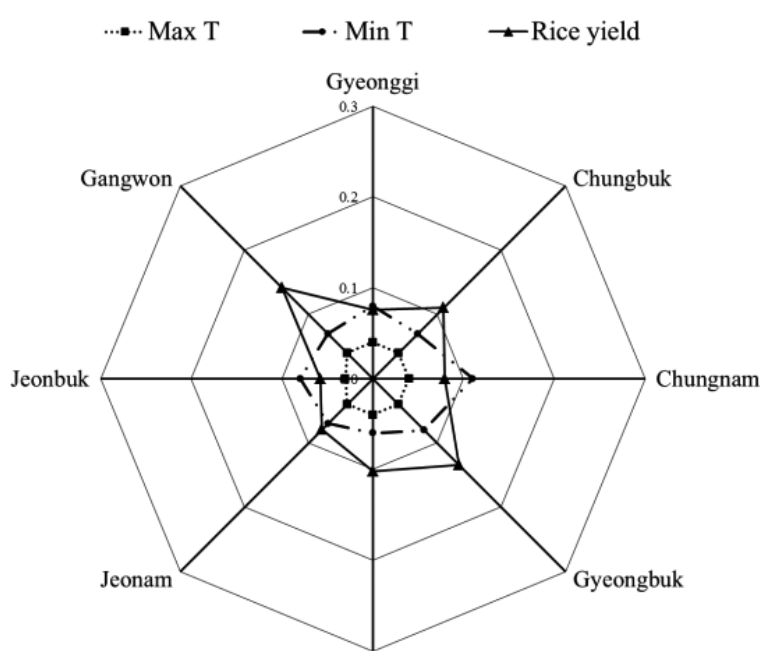

(b)

Fig. 3 Coefficient of variation: (a) rainfall, sunshine hours, relative humidity and wind speed, (b) max. and min. temperatures and rice yield $(1971 \sim 2000)$.

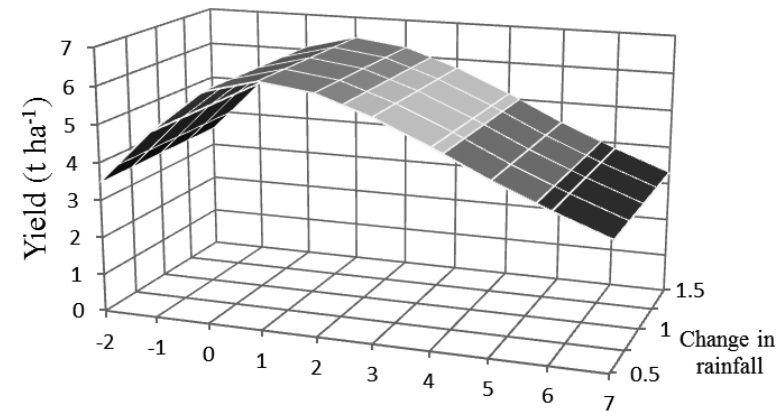

Change in temperature $\left({ }^{\circ} \mathrm{C}\right)$

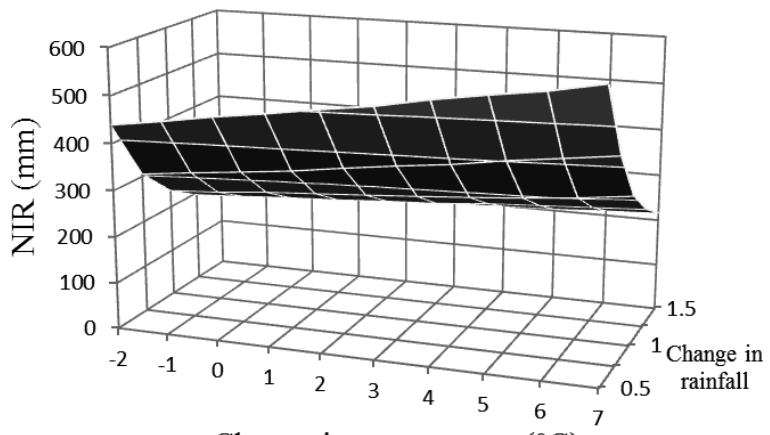

Change in temperature $\left({ }^{\circ} \mathrm{C}\right)$

Fig. 4 Rice yield and NIR responses to changes in temperature and rainfall

above 0.2. Rainfall is most variable in the Northern provinces while the yield is most variable in the eastern provinces. Despite that it is not the thrust of this study; Fig. 3 (a) and (b) show that the results will possess some uncertainty that can be attributed to natural climatic variability.

\section{Crop model sensitivity analysis}

The response surface diagrams presented in Fig. 4 demonstrate the sensitivity of the paddy rice net irrigation water requirement $(\mathrm{mm})$ and potential yield $\left(\mathrm{t} \mathrm{ha}^{-1}\right)$ to changes in ambient air temperature and rainfall. The potential yield is shown to peak at an increase in temperature of $1{ }^{\circ} \mathrm{C}$ and decreases as temperature increases further. This is because rice matures quicker at higher temperatures, which shortens the duration of key growth phases resulting in reduced grain yield (Semenov et al., 2012). The NIR increases as the temperature increases due to the increased evaporative demand. On the other hand, the NIR decreases as the rainfall increases.

\section{Paddy rice yield}

Fig. 5 shows the variation of the simulated changes in the long-term yield for the 2030s, 2060s and 2090s compared to the baseline (1971 2000). Yield for the RCP2.6 generally remained more or less equal to the baseline values. There is convergence for the RCP4.5 and RCP8.5 that the paddy 

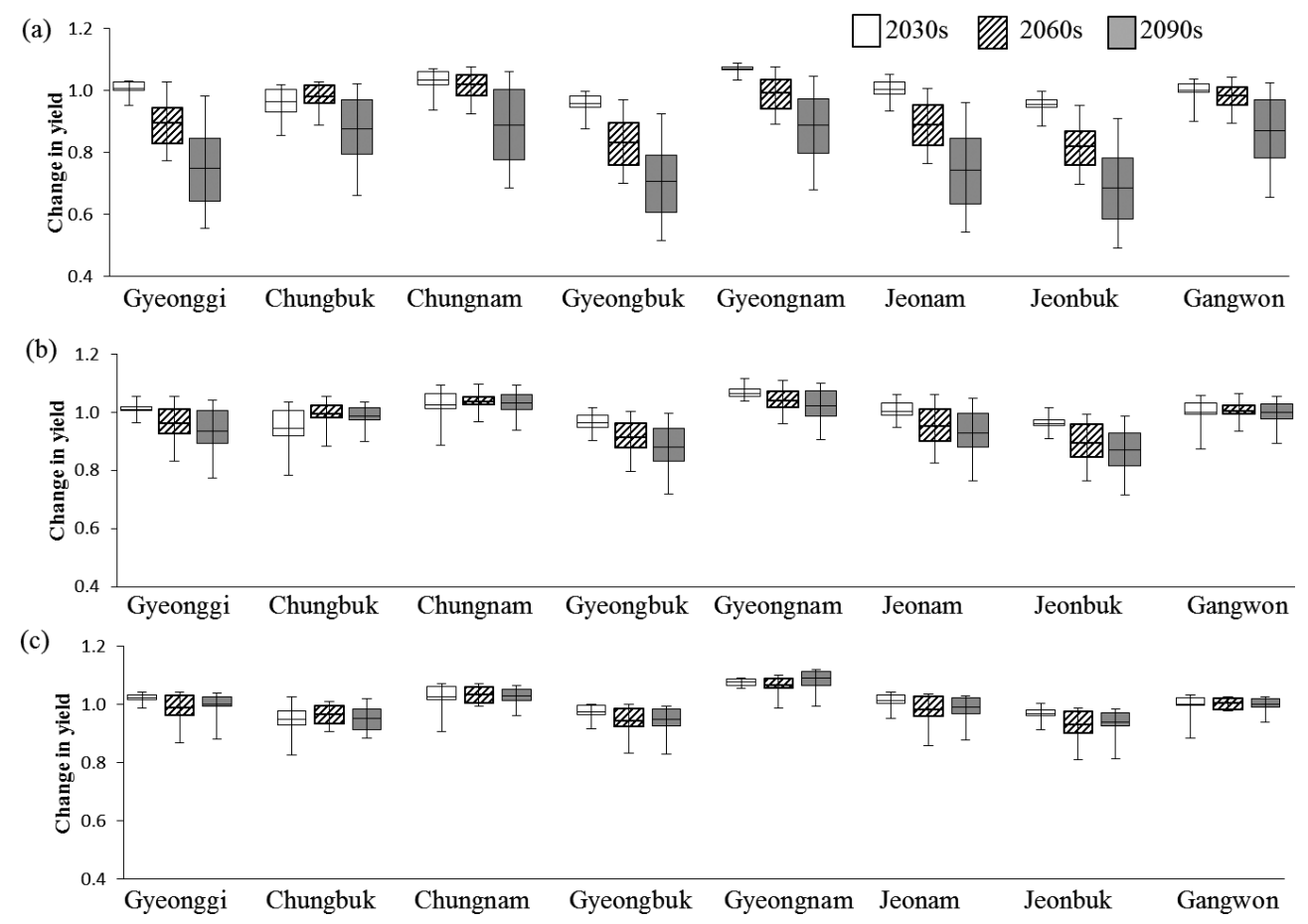

Fig. 5 Projected relative changes in paddy rice yield for (a) RCP8.5 (b) RCP4.5 (c) RCP2.6

rice yields will decrease in the future. Masutomi et al. (2009) also found that the higher greenhouse gas concentration projectiles showed larger decreases in yield in spite of the $\mathrm{CO}_{2}$ fertilization effect and suggested immediate climate change adaptive and mitigation strategies. The decrease in yield was attributed to shortening of the growing season (SGS) and decreasing harvesting index in the future. The decreases in the yield are higher in the RCP8.5 than for the RCP4.5. The changes in yield ranged from $0.93 \sim 1.08,0.87$ $\sim 1.07$ and $0.69 \sim 1.07$ for RCP2.6, RCP4.5 and RCP8.5, respectively. Similarly, the variability (uncertainty) in the simulated yield increases in the future and with the RCPs. The interquartile range ranged from $0.02 \sim 0.07,0.01 \sim 0.12$ and $0.01 \sim 0.23$ for RCP2.6, RCP4.5 and RCP8.5, respectively. Although the differences across the provinces appear small in relative values presented in Fig. 5, the absolute difference of yields between the provinces is large. Overall, the rice yields in Jeonbuk will be most affected while the yield Gyeongnam and Chungnam will be least affected.

\section{Net irrigation water requirement}

Fig. 6 shows the variation in the simulated changes in NIR. There is general model agreement and the NIR is projected to increase in the future scenarios. There is a continuing increasing trend for the RCP4.5 and RCP 8.5. For the RCP2.6, the NIR increases from the baseline values, peaks in the 2060s and slightly declines towards the 2090s. The changes in the NIR ranged from 1.0 1.27, 1.02 1.24 and $0.99 \sim 1.26$ for the RCP2.6, RCP4.5 and RCP8.5, respectively. The trend patterns shown by the NIR can be attributed to the increases in temperature and subsequently evapotranspiration demand for the different RCPs. The interquartile range ranged from $0.04 \sim 0.20,0.04 \sim 0.22$ and $0.02 \sim 0.21$ for the RCP2.6, RCP4.5 and RCP8.5, respectively. There is significantly higher changes and uncertainty (range and interquartile range) for the NIR than for the yield.

Finally, Table 3 shows the irrigation water use efficiency (IWUE) $\left(\mathrm{kg} \mathrm{ha}^{-1} \mathrm{~mm}^{-1}\right)$. Climate change potentially threatens rice production in the Gyeongbuk, Chungnam and the Chungbuk provinces for which the irrigation water use efficiency is projected to be lowest in the future particularly in the 2090s for RCP8.5. The highest decreases in the yield were also projected for these 3 provinces. The highest efficiency is projected for the Gyeonggi, Gyeongnam and Jeonam provinces. For the RCP2.6 the RCP slightly troughs in the 2060s but recovers in the 2090s. For the RCP4.5 and 


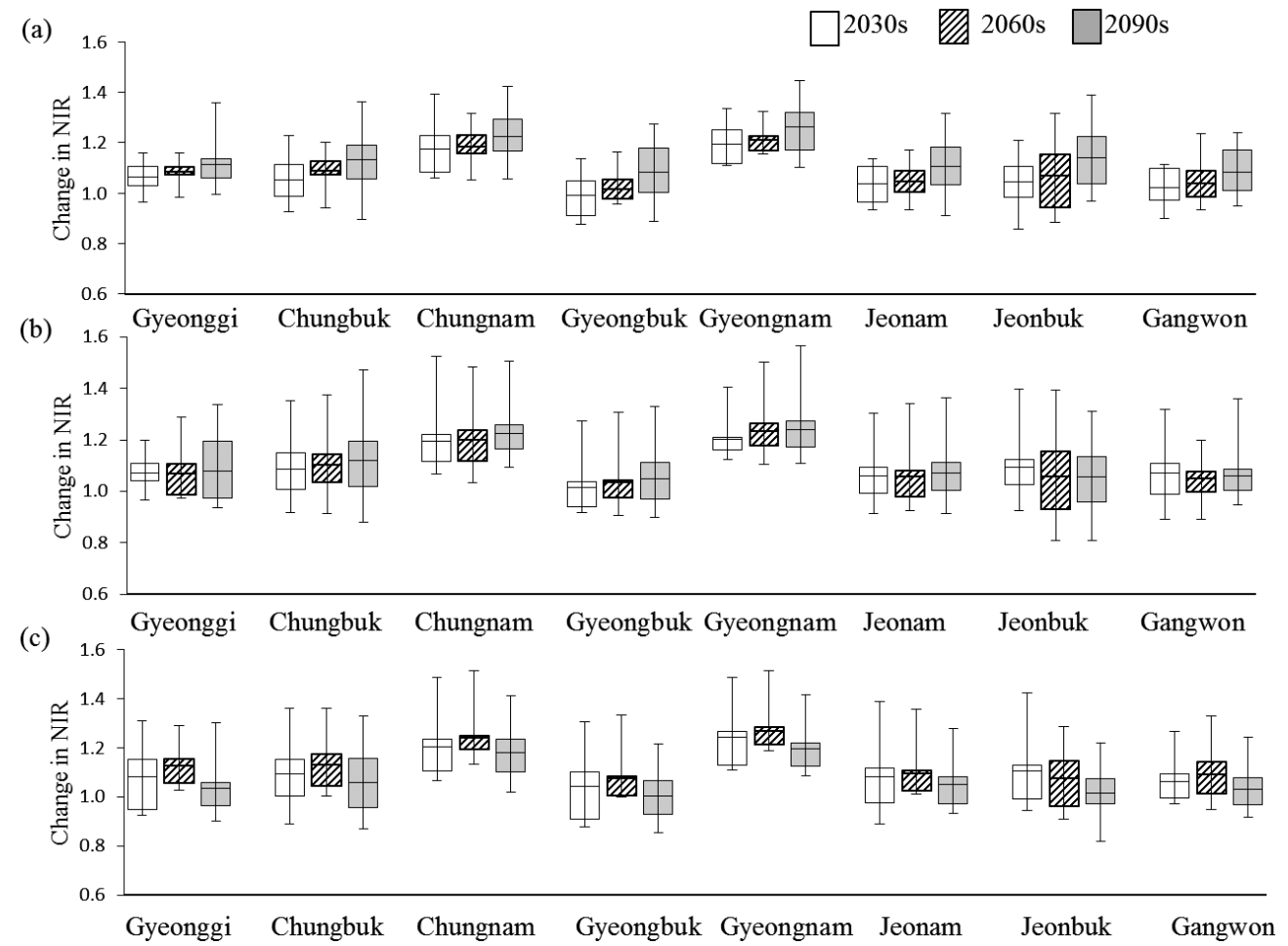

Fig. 6 Projected relative changes in the simulated Net Irrigation Requirement (NIR) for (a) RCP8.5 (b) RCP4.5 (c) RCP2.6

Table 3 Irrigation water use efficiency (IWUE) and the standard deviation in parenthesis $\left(\mathrm{kg} \mathrm{ha}^{-1} \mathrm{~mm}^{-1}\right)$

\begin{tabular}{c|c|c|c|c|c|c|c|c|c}
\hline \multirow{2}{*}{ Province } & \multicolumn{3}{|c|}{ RCP2.6 } & \multicolumn{3}{c|}{ RCP4.5 } & \multicolumn{3}{c}{ RCP8.5 } \\
\cline { 2 - 11 } & 2030s & $2060 s$ & $2090 s$ & $2030 s$ & $2060 s$ & $2090 s$ & $2030 s$ & $2060 s$ & $2090 s$ \\
\hline \hline \multirow{2}{*}{ Gyeongi } & 21.8 & 20.1 & 22.2 & 21.5 & 20.7 & 20.0 & 20.6 & 18.1 & 14.9 \\
& $(2.7)$ & $(2.0)$ & $(2.3)$ & $(1.5)$ & $(2.4)$ & $(2.9)$ & $(3.6)$ & $(3.8)$ & $(4.2)$ \\
\hline \multirow{2}{*}{ Chungbuk } & 17.4 & 17.0 & 18.0 & 17.4 & 17.9 & 17.6 & 17.3 & 17.8 & 14.8 \\
& $(2.6)$ & $(1.6)$ & $(2.9)$ & $(2.6)$ & $(2.0)$ & $(2.4)$ & $(3.3)$ & $(1.8)$ & $(4.1)$ \\
\hline \multirow{2}{*}{ Chungnam } & 17.8 & 17.2 & 18.1 & 17.8 & 17.9 & 17.4 & 17.4 & 17.0 & 14.5 \\
& $(2.3)$ & $(1.5)$ & $(2.2)$ & $(2.1)$ & $(1.7)$ & $(1.5)$ & $(3.2)$ & $(3.2)$ & $(3.9)$ \\
\hline \multirow{2}{*}{ Gyeongbuk } & 16.6 & 15.4 & 16.7 & 16.6 & 15.5 & 14.8 & 16.2 & 13.7 & 11.1 \\
& $(2.3)$ & $(1.5)$ & $(2.0)$ & $(1.6)$ & $(1.9)$ & $(2.1)$ & $(3.1)$ & $(3.1)$ & $(3.5)$ \\
\hline \multirow{2}{*}{ Gyeongnam } & 23.9 & 22.8 & 24.4 & 24.2 & 23.2 & 22.6 & 23.4 & 21.4 & 18.6 \\
& $(2.6)$ & $(1.7)$ & $(2.4)$ & $(1.6)$ & $(2.2)$ & $(2.2)$ & $(4.1)$ & $(4.2)$ & $(4.6)$ \\
\hline \multirow{2}{*}{ Jeonam } & 20.5 & 19.4 & 20.5 & 20.6 & 19.6 & 18.8 & 19.9 & 17.6 & 14.1 \\
& $(2.8)$ & $(1.9)$ & $(2.4)$ & $(2.2)$ & $(2.4)$ & $(2.4)$ & $(3.8)$ & $(4.0)$ & $(4.3)$ \\
\hline \multirow{2}{*}{ Jeonbuk } & 19.7 & 19.3 & 20.6 & 19.6 & 19.1 & 18.5 & 19.4 & 16.3 & 12.9 \\
& $(2.8)$ & $(2.6)$ & $(2.2)$ & $(2.0)$ & $(3.4)$ & $(2.9)$ & $(4.3)$ & $(4.1)$ & $(3.7)$ \\
\hline \multirow{2}{*}{ Gangwon } & 19.2 & 18.9 & 19.9 & 19.0 & 19.6 & 19.3 & 19.0 & 18.4 & 15.8 \\
& $(1.9)$ & $(1.9)$ & $(2.3)$ & $(2.3)$ & $(1.8)$ & $(1.8)$ & $(3.6)$ & $(3.8)$ & $(3.9)$ \\
\hline
\end{tabular}

RCP8.5, the IWUE generally decreases in the future with the highest decreases in the RCP8.5. This could imply worsening the vulnerability of farmers' livelihoods and therefore exacerbate the difficulties and uncertainty already existent.
This study possesses an advantage over studies in which a single or few GCMs are used. A disadvantage in using a few GCMs is that the projected impacts of climate change depend will be largely biased. The large variations shown in Fig. 5 and 6 particularly in the 2090s reveal the large disagreement among GCMs. The possible decreases in yield and increases in the water requirement projected herein have been previously projected for Korea (Kim et al., 2013; Chung and Nkomozepi, 2012) therefore, it is apparent that immediate adaptation and mitigation measures should be implemented. Advances in irrigation technology such as the use of real time climatic data instead of long-term average data would lead to in increased water use efficiency (Masoud et al., 2013). On the same token, alternative management practices and developing new crop genotypes will also help increase crop yields (Kim et al., 2013).

In this paper, the direct effect of $\mathrm{CO}_{2}$ and the advances in technology on future rice yields and water application were not considered. The neglect of direct $\mathrm{CO}_{2}$ fertilization is justified because research has shown that although paddy rice yield increases significantly by doubling the $\mathrm{CO}_{2}$ concentration at current temperatures, if the temperature also 
increases, there is no $\mathrm{CO} 2$ enrichment effect on rice yield at higher temperatures (Kim et al., 1996; Ziska et al., 1997; Yang et al., 2013).

\section{CONCLUSION}

This paper outlines techniques for generating ensembles of climate change scenarios and projecting the potential impacts of climate on the yield and the irrigation water demand. There was general agreement from the $12 \mathrm{GCM}$ ensemble that both temperature and rainfall will increase in the future. Simulations with the Water Accounting Rice Model (WARM) showed that the increased temperatures would lead to reduced rice yield by mean (range) of $12 \%$ (2 to $18 \%$ ) by 2100, attributed to shortening of the growing season (SGS) and decreasing harvesting index in the future. The baseline irrigation demand was projected to increase by up to $27 \%$ by 2100 . With the exception of RCP2.6, the irrigation water use efficiency generally decreases in the future with the higher decreases shown for the RCP 8.5. There is high spatial and GCM uncertainty of the simulated impacts on yield and irrigation demand. These results of this study imply that that the higher greenhouse gas concentration projectiles (RCPs) showed larger decreases in yield, larger increases in irrigation water demand and decrease in water efficiency. Therefore immediate mitigation and adaptation strategies are required to avoid the potential deterioration of rice production in the Chungbuk, Chungnam and Gyeongbuk provinces due to climate change. Further research should be carried out to investigate how Korean farmers can reduce water withdrawal and increase the effective rainfall use and yields in the future.

\section{REFERENCES}

1. Angulo, C., R. Rötter, R. Lock, A. Enders, S. Fronzek, and F. Ewert, 2013. Implication of crop model calibration strategies for assessing regional impacts of climate change in Europe. Agricultural and Forest Meteorology 170: $32-46$.

2. Asseng, S., F. Ewert, C. Rosenzweig, J. W. Jones, J. L. Hatfield, A. C. Ruane, and J. R. Williams, 2013. Uncertainty in simulating wheat yields under climate change. Nature Climate Change 3: 827-832.

3. Chung, S.-O., 2013. "Projecting Future Paddy Irrigation Demands in Korea." Irrigation and Drainage 62(3): 297-305.

4. Chung, S. O., and T. Nkomozepi, 2012. Uncertainty of paddy irrigation requirement estimated from climate change in the Geumho river basin, Korea. Paddy and Water Environment 10(3): 175-185.

5. Confalonieri R., D., Gusberti and M. Acutis, 2006. Comparison of WOFOST, CropSyst and WARM for simulating rice growth (Japonica type - short cycle varieties). Italian Journal of Agrometeorology 11-3: 7-16.

6. Confalonieri, R., G. Bellocchi, S. Bregaglio, M. Donatelli, and M. Acutis, 2010. Comparison of sensitivity analysis techniques: a case study with the rice model WARM." Ecological Modelling 221(16): 1897-1906.

7. Confalonieri, R., M. Acutis, G. Bellocchi, and M. Donatelli, 2009. Multi-metric evaluation of the models WARM, CropSyst, and WOFOST for rice. Ecological Modelling 220(11): 1395-1410.

8. Dastane, N. G., 1978. "Effective Rainfall in Irrigated Agriculture. FAO Irrigation and Drainage Paper No. 25." Food and Agriculture Organization (FAO), Rome, Italy, $67 \mathrm{pp}$.

9. Djaman, K., and S. Irmak, 2013. Actual Crop Evapotranspiration and Alfalfa- and Grass-Reference Crop Coefficients of Maize under Full and Limited Irrigation and Rainfed Conditions. Journal of Irrigation and Drainage Engineering 139(6): 433-446.

10. Guerra, L., S. I. Bhuiyan, T. P. Tuong, and R. Barker, 1998. Producing more rice with less water. SWIM Paper 5. Colombo, Sri Lank: International Water Management Institute, 4-6.

11. Jang, M.-W., J.-Y. Choi, J.-J. Lee, 2007. A spatial reasoning approach to estimating paddy rice water demand in Hwanghaenam-do, North Korea. Agricultural water management 89: 185-198.

12. Kim, H. K., P. B. Parajuli, and S. D. Filip To, 2013 Assessing impacts of bioenergy crops and climate change on hydrometeorology in the Yazoo River Basin, Mississippi. Agricultural and Forest Meteorology 169: 61-73. 
13. Kim, H. Y., T. Horie, H. Nakagawa, and K. Wada, 1996. Effects of elevated $\mathrm{CO}_{2}$ concentration and high temperature on growth and yield of rice [Oryza sativa], 2: The effect on yield and its components of Akihikari rice. Japanese Journal of Crop Science 65(4): 644651.

14. Kim, J., J. Shon, C.K. Lee, W. Yang, Y. Yoon, W.H. Yang, and B.W. Lee, 2011. "Relationship between grain filling duration and leaf senescence of temperate rice under high temperature. Field Crops Research 122(3): 207-213.

15. Ledbetter R., C. Prudhomme, and N. Arnell, 2012. A method for incorporating climate variability in climate change impact assessments: Sensitivity of river flows in the Eden catchment to precipitation scenarios." Climatic Change 113(3-4): 803-823.

16. Lupia, F., 2013. ETo-PM version 0.9. http://dspace. inea.it, accessed 4 July, 2013.

17. Masoud, P., Yazdi, A. B., S. Araghinejad, A. P. Nejadhashemi, and M. S. Tabrizi, 2013. Optimal water allocation in irrigation networks based on real time climatic data. Agricultural Water Management 117: 1-8.

18. Masutomi, Y., K. Takahashi, H. Harasawa, and Y. Matsuoka, 2009. Impact assessment of climate change on rice production in Asia in comprehensive consideration of process/parameter uncertainty in general circulation models.

19. Mehta, V. K., V. R. Haden, B. A. Joyce, D. R. Purkey, and L. E. Jackson, (2013), "Irrigation demand and supply, given projections of climate and land-use change, in Yolo County, California." Agricultural Water Management 117: 70-82.

20. Semenov, M. A., R. A. C. Mitchell, A. P. Whitmore, M. J. Hawkesford, M. A. J. Parry, and P.R. Shewry, 2012. Shortcomings in wheat yield predictions. Nature Climate Change 2(6): 380-382.
21. Supit, I., C. A. Van Diepen, A. J. W. De Wit, J. Wolf, P. Kabat, B. Baruth, and F. Ludwig, 2012. Assessing climate change effects on European crop yields using the Crop Growth Monitoring System and a weather generator. Agricultural and Forest Meteorology 164: 96-111.

22. Tallec, T., P. Béziat, N. Jarosz, V. Rivalland, and E. Ceschia, 2013. Crops' water use efficiencies in temperate climate: Comparison of stand, ecosystem and agronomical approaches. Agricultural and Forest Meteorology 168: 69-81.

23. Van Minnen, J. G., J. Alcamo, and W. Haupt, 2000. Deriving and applying response surface diagrams for evaluating climate change impacts on crop production. Climatic Change 46: 317-338.

24. Weatherhead, E. K., and J. W. Knox, 2000. Predicting and mapping the future demand for irrigation water in England and Wales. Agricultural Water Management 43: 203-218.

25. Yang, W., H. S. Cho, M. Kim, K. Y. Seong, T. S. Park, M. C. Seo, and H. W. Kang, 2013. "Re-examination of the standard cultivation practices of rice in response to climate change in Korea." Journal of Crop Science and Biotechnology 16(2): 85-92.

26. Yoo, S.-H., J.-Y. Choi, S.-H. Lee, Y.-G. Oh, and D.-K. Yun, 2013. Climate change impacts on water storage requirements of an agricultural reservoir considering changes in land use and rice growing season in Korea. Agricultural Water Management 117: 43-54.

27. Ziska, L. H., O. Namuco, T. Moya, and J. Quilang, 1997. Growth and Yield Response of Field-Grown Tropical Rice to Increasing Carbon Dioxide and Air Temperature." Agronomy Journal 89: 45-53. 